\title{
Comparison of PAH Mass Concentrations in Aerosols of the Middle Adriatic Coast Area and Central Croatia
}

\author{
1. Jakovljević, ${ }^{*}$ Z. Sever Štrukil,a G. Pehnec, a I. Bešlić,

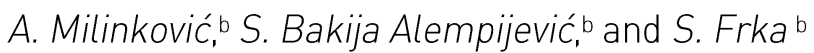 \\ a Institute for Medical Research and Occupational Health, Ksaverska cesta 2, Zagreb, Croatia \\ b Division for Marine and Environmental Research, Ruđer Bošković Institute, \\ Bijenička c. 54, Zagreb, Croatia
}

This work is licensed under a Creative Commons Attribution 4.0 International License

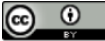

\begin{abstract}
Polycyclic aromatic hydrocarbons (PAHs) are considered priority pollutants due to their distribution, persistence, bioaccumulation, and adverse effects on human health. The aim of this study was to obtain the first insight into PAHs mass concentrations bound to airborne particulate matter (PM) in the mid Adriatic coast area of Croatia, and compare them with the PAH levels in Croatia's urban central area. Relatively low values of PAH mass concentrations were measured in the coastal area, compared to the continental urban region of Croatia impacted by increased emissions due to intensive traffic, industry, and residential heating. A high $\mathrm{PM}_{10}$ contribution of four-ring PAHs (Flu and Pyr) at Martinska site indicated that wood burning heating as well as open fire events, including waste incineration, could be important emission sources of PAHs in the mid Adriatic coast region.
\end{abstract}

Keywords

Air pollution, PAH, HPLC, BaP, particulate matter, coastal Croatia

\section{Introduction}

Particulate matter (PM) is a major pollutant that can affect air quality, and human and ecosystem safety. ${ }^{1,2}$ The term "particulate matter" or "aerosol" refers to the dispersed liquid and/or solid phase in the air. Sources of PM can be both natural and anthropogenic; it can be emitted as primary particles (directly emitted into atmosphere) or formed by secondary processes (transformation of emitted precursor gases) in the atmosphere. Adverse health effects linked to PM exposure distress, mostly but not exclusively the respiratory and cardiovascular system, ${ }^{3}$ as the PM fraction can adsorb greater concentrations of toxic compounds, such as polycyclic aromatic hydrocarbons (PAHs). ${ }^{4}$ Particulate matter with an equivalent aerodynamic diameter less than $10 \mu \mathrm{m}\left(\mathrm{PM}_{10}\right)$ and less than $2.5 \mu \mathrm{m}\left(\mathrm{PM}_{2.5}\right)$ is of major concern in terms of harmful effects on health and environment. ${ }^{1}$

PAHs are a product of the incomplete combustion and pyrolysis of organic materials. Transport (land, water, and air) is considered one of the main PAHs sources, as are many industrial processes, such as asphalt production, coal and coke production, iron/steel production, waste incineration, oil refining, etc. In urban areas, motor vehicle exhausts and residential heating have been identified as the most significant sources of airborne PAHs. ${ }^{5,6}$ In the atmosphere, PAHs occur as a complex mixture of compounds with different structures and molecular weights. Most measurements have been made on benzo(a)pyrene (BaP). The Environmental Protection Agency (EPA) has classified 16 priority PAHs; these PAHs were selected because the majority of data that related to adverse health effects referred to them. ${ }^{7}$ In this study, due to limitation of chromatography detection, only 11 out of 16 priority PAHs were measured (fluoranthene (Flu), pyrene (Pyr), benzo(a)anthracene (BaA), benzo(b)fluoranthene $(B b F)$, benzo(k)fluoranthene $(B k F)$, benzo(j)fluoranthene (BjF), benzo(a)pyrene (BaP), dibenzo(a,h)anthracene (DahA), benzo(ghi)perylene (BghiP), and indeno(1,2,3-cd)pyrene (IP)). Some PAHs were characteristic for domestic heating or biomass burning (Flu, Pyr), while BghiP, BbF, IP were specific for car exhausts. ${ }^{8}$ PAHs with two and three aromatic rings are present almost exclusively in the vapour phase, and due to their lower molecular weight they are usually called lighter PAHs. PAHs with four or more aromatic rings are mostly adsorbed on particulate matter and are called heavy PAHs. Because of their stability, particle-bounded PAHs persist in the atmosphere for a long time and can be transported

*Corresponding author: Ivana Jakovljević, PhD

e-mail: ijakovljevic@imi.hr 
over long distances from their original emission sources. ${ }^{9}$ Based on experimental results, the most significant health effect to be expected from inhalation exposure to PAHs is an excess risk of lung cancer. ${ }^{1}$

$\mathrm{PM}_{10}$ measurements are performed in Croatia and Europe within national and international monitoring networks. Mass concentrations of PAHs have been continuously measured in Zagreb for more than ten years, but until now, there has been no data for the middle Adriatic coast area of Croatia; the only known data was reported for the North Adriatic area (Rijeka). ${ }^{10}$ This paper represents the first measurements of PAHs in the mid Adriatic coast area of Croatia. The aim of this study was to compare the levels of particle-bounded PAHs at two urban locations in continental Croatia with the first PAH data obtained for the coastal and mid Adriatic area. Measurements were carried out within the project "Biochemical responses of oligotrophic Adriatic surface ecosystems to atmospheric deposition inputs (BiREADI)". The main goal of the project is to evaluate concentrations, sources, and deposition fluxes of atmospheric constituents, including organic pollutants in the largely unexplored Adriatic coast of Croatia. As there is no available data on the $\mathrm{PAH}$ composition of ambient aerosols in the mid Adriatic coast, the present study provides valuable background knowledge to better understand the variabilities of organic pollutants as well as the air quality conditions in coastal regions of Croatia.

\section{Experimental}

\subsection{Study area and sampling of PM}

$\mathrm{PM}_{10}$ sampling in the mid Adriatic coast area was carried out at the Ruđer Bošković Institute's research station Martinska $\left(43^{\circ} 73^{\prime} \mathrm{N}, 15^{\circ} 87^{\prime} \mathrm{E}\right)$ (Fig. 1). Martinska station is located in the lower part of the Krka River estuary near the city of Šibenik (population 34.302), situated in the central part of the eastern Adriatic coast. The area is affected by arid Mediterranean conditions. Meteorological parameters such as air temperature, relative humidity, and wind speed were measured at 10-min intervals using instruments situated at the measurement site. Air temperature ranged from $6{ }^{\circ} \mathrm{C}$ to $30^{\circ} \mathrm{C}$ with an average value of $16.7^{\circ} \mathrm{C}$. Relative humidity ranged from $25.6 \%$ to $83 \%$, an average value of $55.4 \%$. Maximum wind speed ranged from $1.4 \mathrm{~m} \mathrm{~s}^{-1}$ to $15.1 \mathrm{~m} \mathrm{~s}^{-1}$ with an average of $6.4 \mathrm{~m} \mathrm{~s}^{-1}$. During summer, the area is especially exposed to permanent and very high fire risks, and has a long history of extreme forest fires. Two-day (48-hour) samples of $\mathrm{PM}_{10}$ particle fraction were continuously collected on quartz filters (Whatman, QM-A Quartz Microfibre Filters, $47 \mathrm{~mm}$ in diameter) using a sequential low-volume reference device Sven Leckel Sequential Sampler SEQ47/50 (Sven
Leckel, Inginierbüro, Berlin, Germany) equipped with a $\mathrm{PM}_{10}$ cut off inlet. In the period from February 6 to July 8, 2019, 77 samples of $\mathrm{PM}_{10}$ particle fraction were collected.

The capital of Croatia, Zagreb, is located in the continental, central part of the country. The $\mathrm{PM}_{10}$ samples regarding Zagreb were collected within this study at two measuring stations, located in the south and north of Zagreb. Both stations are part of the local network for continuous air quality monitoring, funded by the City of Zagreb, City Office for Economy, Energy, and Environmental Protection. The south measuring site is located in the residential part of the town with high population density and intensive traffic. The site is influenced by winds from the north (town centre) and the southeast (low-rise residential area with residential heating relying mostly on gas, oil, or wood). The sampler is located approximately $4 \mathrm{~m}$ above ground, and about $30 \mathrm{~m}$ from the nearest road. The north measuring site is located in the residential part of town, about $20 \mathrm{~m}$ from a street with modest traffic density. The site is surrounded with family houses. Residential heating in the northern part of Zagreb relies mostly on gas, but some households still use wood for heating and cooking. Pollution at this site originates from domestic furnaces and moderate traffic. The sampler is set at about $1.5 \mathrm{~m}$ above ground.

Metrological conditions for Zagreb were taken from the Maksimir station, the regular monitoring station of the Croatian air pollution monitoring network. Air temperature ranged from $-0.1{ }^{\circ} \mathrm{C}$ to $28.6{ }^{\circ} \mathrm{C}$ with an average value of $13.7^{\circ} \mathrm{C}$. Relative humidity was in the range from $41 \%$ to $91 \%$, average relative humidity of $66 \%$. Maximum wind speed ranged from $0 \mathrm{~m} \mathrm{~s}^{-1}$ to $8.4 \mathrm{~m} \mathrm{~s}^{-1}$ with an average value of $1.4 \mathrm{~m} \mathrm{~s}^{-1}$.

At both Zagreb locations, 24-hour samples of $\mathrm{PM}_{10}$ particle fraction were collected on quartz filters (Whatman, QM-A Quartz Microfibre Filters, $47 \mathrm{~mm}$ in diameter) using a sequential low-volume reference device Sven Leckel Sequential Sampler SEQ47/50 (Sven Leckel, Inginierbüro, Berlin, Germany) equipped with a $\mathrm{PM}_{10}$ cut off inlet. In the period from February 6 to July 8, 2019, 153 samples of $\mathrm{PM}_{10}$ particle fraction were collected.

The locations of the measuring sites are presented in Fig. 1.

\section{2 $\mathrm{PM}_{10}$ mass concentration}

Concentrations of the $\mathrm{PM}_{10}$ particle fraction were determined gravimetrically (Mettler Toledo MX-5 micro balance) according to standard EN 12341:2014 "Ambient air - Standard gravimetric measurement method for the determination of $\mathrm{PM}_{10}$ or $\mathrm{PM}_{2.5}$ mass concentration of suspended particulate matter". 


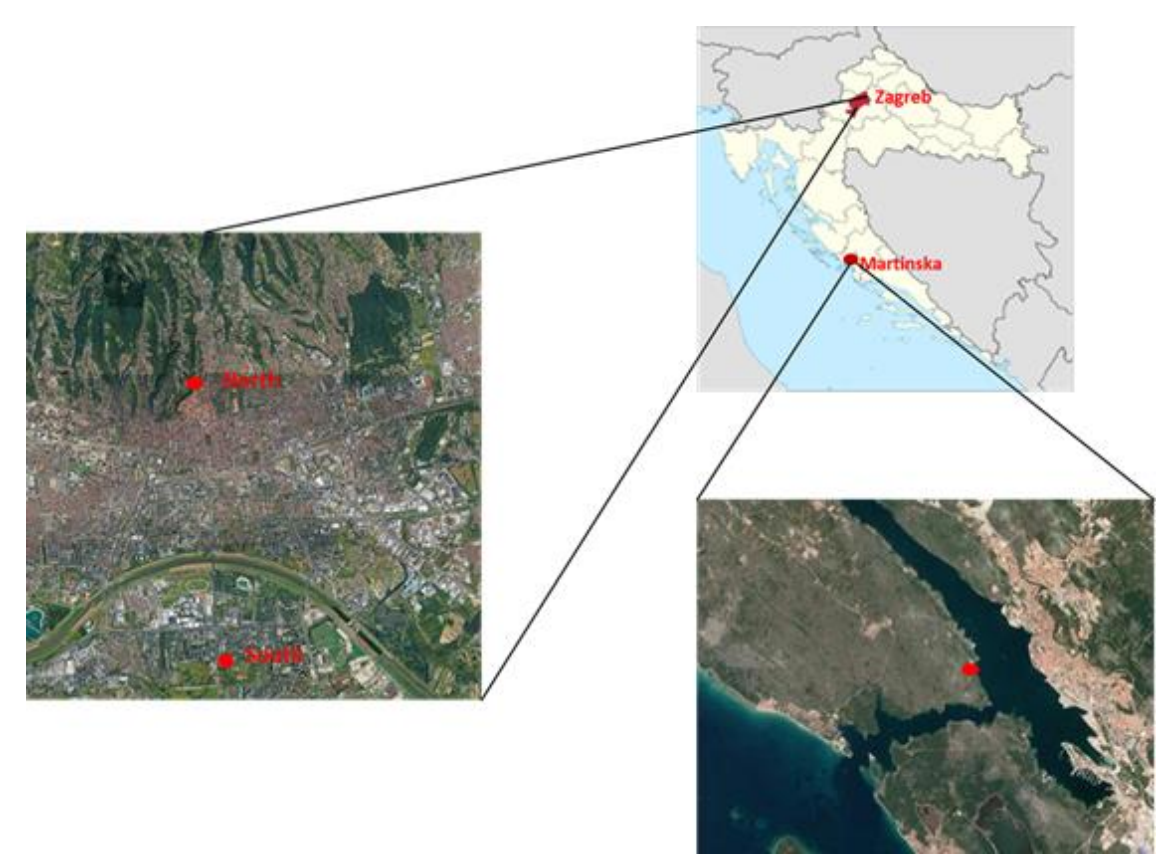

Fig. 1 - Locations of measuring sites

Slika 1 - Lokacije mjernih mjesta

\subsection{PAH analysis}

Filter aliquots were extracted in an ultrasonic bath with a solvent mixture of cyclohexane and toluene $(3: 7)$, separated from undissolved parts by centrifugation (10 min, $3000 \mathrm{rpm}$ ), and evaporated to dryness in a mild stream of nitrogen at $30^{\circ} \mathrm{C}$. Afterwards, they were redissolved in acetonitrile. The analysis was performed using Agilent Infinity 1260 high-performance liquid chromatography (HPLC) with a fluorescence detector. PAHs were separated by an Eclipse PAH stainless steel column $(100 \times 4.6 \mathrm{~mm})$. The mobile phase was a mixture of water and acetonitrile $(40: 60),{ }^{11-13}$ and the flow rate was $1 \mathrm{ml} \mathrm{min}{ }^{-1}$. Samples were analysed for the following PAHs: fluoranthene (Flu), pyrene (Pyr), benzo(a)anthracene $(\mathrm{BaA})$, benzo(b)fluoranthene $(\mathrm{BbF})$, benzo(k)fluoranthene $(\mathrm{BkF})$, benzo(j)fluoranthene $(\mathrm{BjF})$, benzo(a)pyrene (BaP), dibenzo(a,h)anthracene (DahA), benzo(ghi)perylene (BghiP), and indeno(1,2,3-cd)pyrene (IP).

\section{Results and discussion}

Average mass concentrations of specific PAHs at Martinska and Zagreb, for the period February - July 2019, are presented in Fig. 2. In general, the average concentrations of the measured PAHs at Martinska were much lower than the concentrations measured at both Zagreb locations. In contrast, the highest average values for overall measured $\mathrm{PAHs}$ were characteristic for Zagreb south. Concentrations of specific PAH compounds at Martinska, Zagreb south and Zagreb north decreased in the following order:
Martinska:

BbF $>$ BghiP $>$ IP $>$ BaP $=$ Flu $>$ Pyr $>$ Chry $>$ BjF $>$ BkF $>$ BaA $>$ $>$ DahA

Zagreb south:

BbF $>$ BghiP $>$ BaP $>$ Chry $>$ IP $>$ BjF $>$ BaA $>$ BkF $>$ Pyr $>$ Flu $>$ $>$ DahA

Zagreb north:

$\mathrm{BbF}>$ BghiP $>\mathrm{IP}>\mathrm{BaP}>$ Chry $>\mathrm{BjF}>\mathrm{BkF}>\mathrm{Flu}>\mathrm{Pyr}>\mathrm{BaA}>$ $>$ DahA

At all three stations, the dominant compound was BbF, followed by BghiP and IP, contributing the most to the $\mathrm{PM}_{10}$ mass concentration at Zagreb south (Fig. 3). The BbF concentrations ranged from 0.039 to $17.440 \mathrm{ng} \mathrm{m}^{-3}$ at Zagreb south, from 0.023 to $4.421 \mathrm{ng} \mathrm{m}^{-3}$ at Zagreb north, and from 0.004 to $0.836 \mathrm{ng} \mathrm{m}^{-3}$ at Martinska, while BghiP ranged from 0.037 to $18.117 \mathrm{ng} \mathrm{m}^{-3}$ at Zagreb south, from 0.027 to $3.408 \mathrm{ng} \mathrm{m}^{-3}$ at Zagreb north, and from 0.005 to $0.782 \mathrm{ng} \mathrm{m}^{-3}$ at Martinska. In Zagreb (south and north), there were also high contributions of Chry and BaA related to pyrolytic origin ${ }^{14}$ and a high contribution of BghiP indicating vehicle emission. ${ }^{7}$ The differences between Zagreb's north and south stations were caused by environmental and geographic circumstances. The south station is in a traffic area and the contribution of six-ringed $\mathrm{PAHs}$ was pronounced much more than at the north station located in an urban background with domestic heating as the dominant source of PAHs that lead to a higher contribution of four-ringed PAHs. ${ }^{11,12}$ At all locations, DahA had the lowest average mass 
concentrations; values ranged from 0.005 to $2.435 \mathrm{ng} \mathrm{m}^{-3}$ at Zagreb's south, from 0.005 to $0.443 \mathrm{ng} \mathrm{m}^{-3}$ at Zagreb north, and from the detection limit to $0.093 \mathrm{ng} \mathrm{m}^{-3}$ at Martinska.

\section{- Martinska Zagreb north NZagreb south}

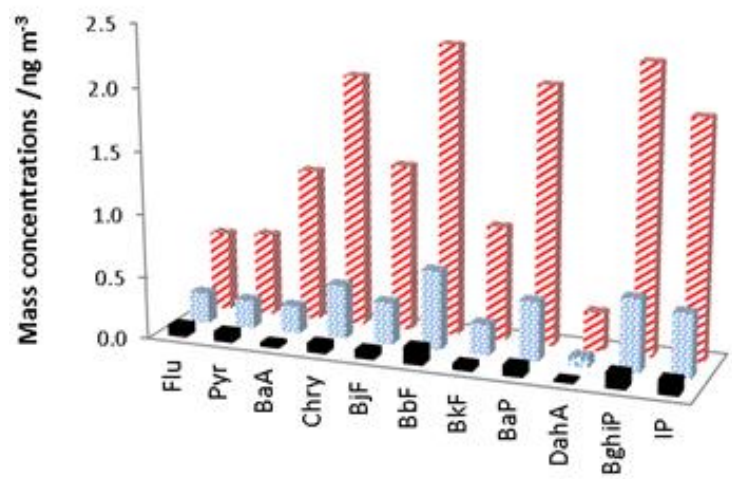

Fig. 2 - Average PAHs mass concentrations for the period February-July 2019

Slika 2 - Srednje masene koncentracije PAU-a za razdoblje veljača-srpanj 2019.

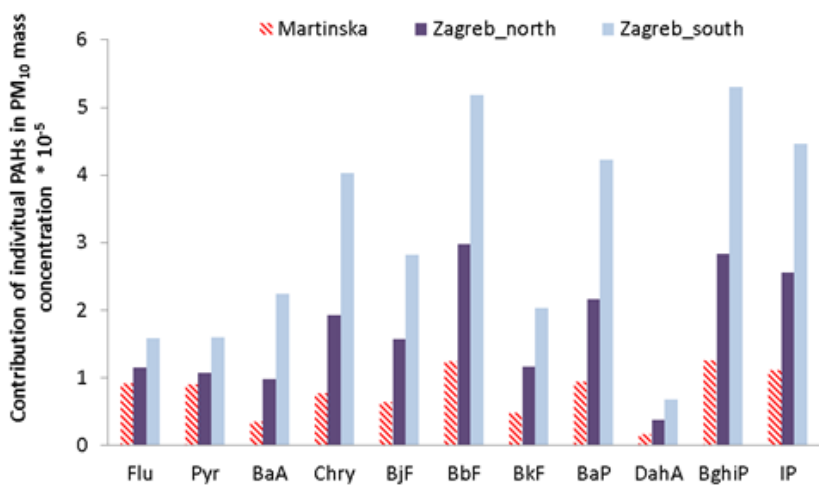

Fig. 3 - Contribution of individual PAHs compounds in the $\mathrm{PM}_{10}$ mass concentration at the three measuring sites

Slika 3 - Zastupljenost pojedinog PAU-a u masi lebdećih čestica $\left(\mathrm{PM}_{10}\right)$ na tri mjerna mjesta

In order to determine partial differences between the measuring sites for all PAHs, non-parametric Kruskal-Wallis ANOVA and post-hoc multiple comparisons (by Siegel and Castellan) tests were used. Thus, PAHs were grouped according to the number of aromatic rings as $\mathrm{PAH}$ groups with: four rings (Fig. 4), five rings (Fig. 5), and six rings (Fig. 6). The results showed highly significant differences (at $p<0.0001$ ) between the PAH concentrations at Martinska and Zagreb south. These strong differences between sites, with the lowest values at Martinska and the highest at Zagreb south, are not surprising, as Martinska is characterised as a suburban site impacted by the Mediterranean climate, lower population density, and lower traffic density during the investigated part of the year (off season), while Zagreb south is in an urban traffic area with high population density and longer heating season, thus, under the influence of much higher possible PAHs emission sources. Although average $\mathrm{PAH}$ concentrations at Zagreb north were lower than those in Zagreb south and more similar to Martinska values, statistically significant differences (at $p<0.0001$ ) between Martinska and Zagreb north were also found for all PAHs. Furthermore, significant differences between Zagreb north and Zagreb south were found for all PAHs, but these differences were stronger $(p<0.0001)$ for PAHs with four aromatic rings (Flu, Pyr, BaA) and for BbF, DahA, BghiP, whereas for BkF, $\mathrm{BaP}$ and IP these differences were less pronounced $(p<0.001)$, as well as for $\operatorname{BjF}(p<0.01)$. These results confirmed those obtained by the contribution of PAHs in the $\mathrm{PM}_{10}$ mass concentration. Two different dominant sources (domestic heating and vehicle exhausts) were in Zagreb, but the first was more pronounced at the north and the second at the south station.

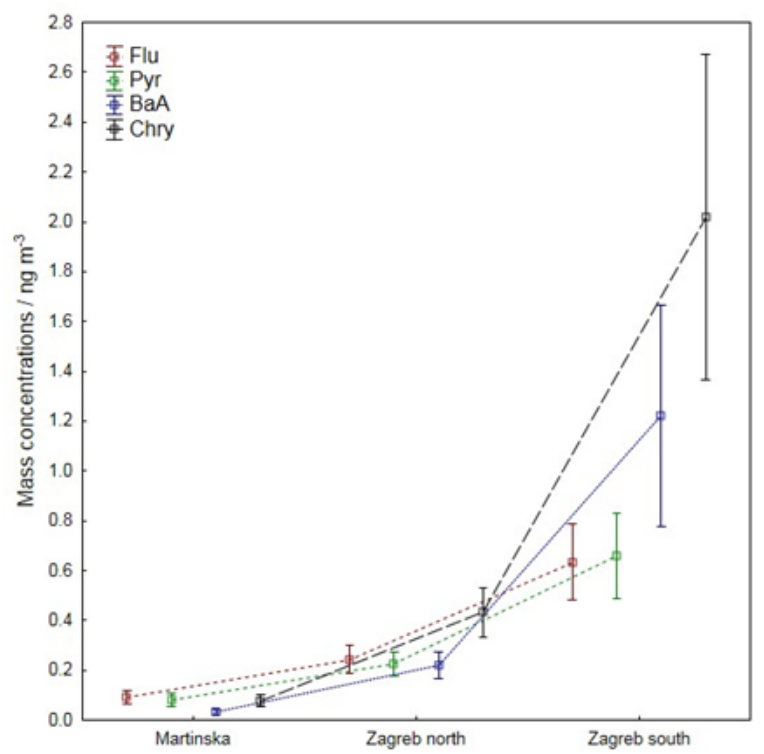

Fig. 4 - Differences between measuring sites in mass concentrations for PAHs with four aromatic rings. Data are presented as mean \pm 0.95 confidence interval. Statistically significant differences between measuring sites (at $p<0.05$ ) were found for all the PAHs (KruskalWallis ANOVA and post-hoc multiple comparisons by Siegel and Castellan test)

Slika 4 - Razlike između masenih koncentracija PAU-a s četiri aromatska prstena za ispitivana područja. Vrijednosti su prikazane kao srednja vrijednost uz s intervalom pouzdanosti $\pm 0,95$. Statistički značajne razlike (at $p<0,05)$ nađene su za sve PAU-e između mjernih mjesta (Kruskal-Wallis ANOVA i post-hoc test višestruke usporedivosti po Siegel i Castellan)

Total concentrations of measured PAHs were calculated as the sum of all 11 measured PAHs during the investigated period. Average total $\mathrm{PAH}$ concentrations were $0.902 \mathrm{ng} \mathrm{m}^{-3}, \quad 3.974 \mathrm{ngm}^{-3}$, and $15.657 \mathrm{ngm}^{-3}$ for Martinska, Zagreb north, and Zagreb south, respectively. Monthly variations of total PAH concentrations are shown 
in Fig. 7. High variabilities between the three measuring locations were observed, especially during the colder months (February, March). One of the reasons could be due to the air temperature variabilities between the measuring sites during the cold months, since during the warm period (May, June, July), the air temperature was similar for all locations studied. Thus, the air temperature was higher at Martinska station (February $9.3^{\circ} \mathrm{C}$, March $12.8^{\circ} \mathrm{C}$ ), while at Zagreb the air temperature was $4.8^{\circ} \mathrm{C}$ and $9.5^{\circ} \mathrm{C}$ for February and March, respectively. During the cold period, differences between the PAH concentrations could also be due to the different emission levels, potentially caused by the variabilities due to a large discrepancy between the number of households and the prevalence of wood-burning heating. In addition to woodburning heating in the cold season, the frequent open fire events could be a source of PAHs emission at the Martinska site. The open-fires are common for the middle Adriatic area in the late winter and early spring months, when the strong March Bora winds rapidly spread uncontrolled burning of agricultural waste into open fires. During measurements at Martinska location, wind speed was higher than in Zagreb, which could resulted in dispersion of particulate matter and the lower $\mathrm{PM}_{10}$ concentrations levels.

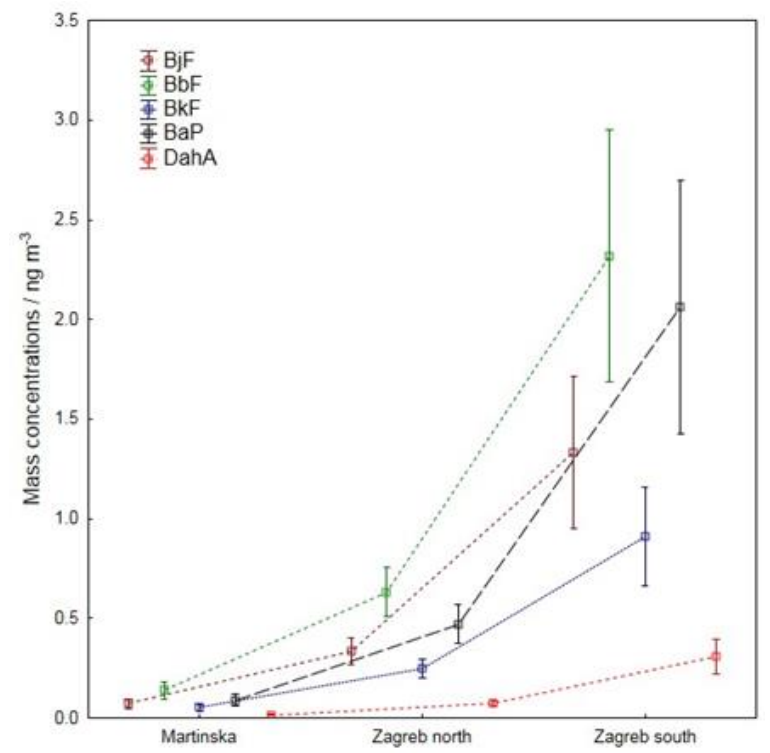

Fig. 5 - Differences between measuring sites in mass concentrations for PAHs with five aromatic rings. Data are presented as mean \pm 0.95 confidence interval. Statistically significant differences between measuring sites (at $p<0.05$ ) were found for all the PAHs (KruskalWallis ANOVA and post-hoc multiple comparisons by Siegel and Castellan test)

Slika 5 - Razlike između masenih koncentracija PAU-a s pet aromatskih prstena za ispitivana područja. Vrijednosti su prikazane kao srednja vrijednost $\mathrm{s}$ intervalom pouzdanosti $\pm 0,95$. Statistički značajne razlike (at $p<0,05)$ nađene su za sve PAU-e između mjernih mjesta (Kruskal-Wallis ANOVA i post-hoc test višestruke usporedivosti po Siegel i Castellan)
In Zagreb, the $\mathrm{PAH}$ concentrations in the $\mathrm{PM}_{10}$ particle fraction obtained in this study are similar or slightly lower than those from some previous studies at the same locations ${ }^{15,16}$ and similar or slightly higher in comparison to some other European urban areas, such as Zaragoza and Monagrega in Spain ${ }^{17}$ and Naples, Italy. ${ }^{18}$ Concentrations of Pyr, BaP and BghiP at Martinska were similar to the concentrations measured in some other coastal cities on the eastern Mediterranean, such as Hersklion, Island of Crete, and Limassol, Cyprus. ${ }^{19}$ Mastral et al. ${ }^{20}$ reported concentrations at different Mediterranean cities such as East Coast of Portuga| ${ }^{20,21}$ and Mallorca, Spain, ${ }^{22}$ all of which had slightly lower values than those measured at Martinska.

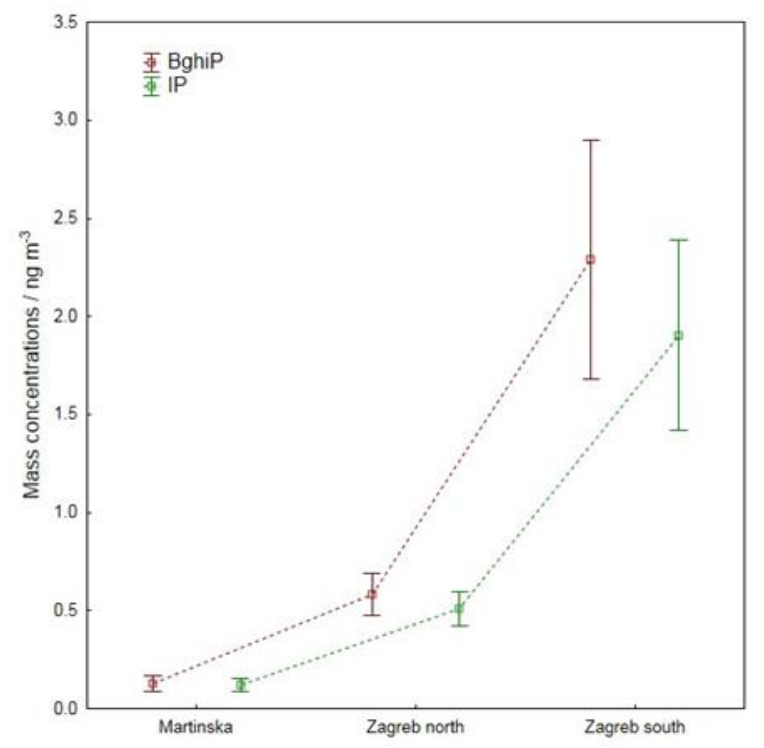

Fig. 6 - Differences between measuring sites in mass concentrations for PAHs with six aromatic rings. Data are presented as mean \pm 0.95 confidence interval. Statistically significant differences between measuring sites (at $p<0.05$ ) were found for all the PAHs (Kruskal-Wallis ANOVA and post-hoc multiple comparisons by Siegel and Castellan test)

Slika 6 - Razlike između masenih koncentracija PAU-a sa šest aromatskih prstena za ispitivana područja. Vrijednosti su prikazane kao srednja vrijednost s intervalom pouzdanosti $\pm 0,95$. Statistički značajne razlike (at $p<0,05)$ nađene su za sve PAU-e između mjernih mjesta (Kruskal-Wallis ANOVA i post-hoc test višestruke usporedivosti po Siegel i Castellan)

Higher annual concentrations of PAHs were also measured in Rijeka, ${ }^{10}$ north Adriatic, than at Martinska. Rijeka is the largest maritime traffic station in Croatia. However, the average concentrations of $\mathrm{BaP}$ as well as the contribution of $\mathrm{BaP}$ to the $\mathrm{PM}_{10}$ mass concentrations at Martinska were higher than those measured in the coastal city of Crotone in southern Italy. ${ }^{14}$ The main sources of BaP are coal and wood domestic heating, and transport-related emissions, as well as heavy industry, combined heat and power plants. ${ }^{7}$ However, significant sources of $\mathrm{BaP}$ are also 
uncontrolled fires and waste incineration. ${ }^{7}$ Thus, domestic heating during the cold season as well as several local/regional agricultural waste burning and intensive open-fire events reported during the investigated period ${ }^{23}$ could explain the elevated BaP levels in the mid Adriatic coast area. This is additionally supported by the high $\mathrm{PM}_{10}$ contributions of four-ringed PAHs, such as Flu and Pyr, characteristic for wood combustion processes at Martinska (Fig. 3), compared to other PAHs at the same location.

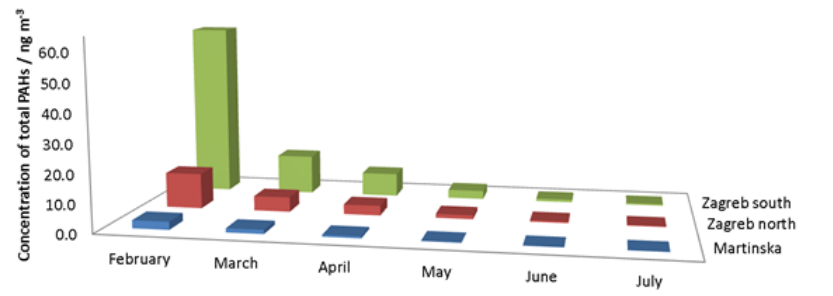

Fig. 7 - Average monthly concentrations of total PAHs in $\mathrm{PM}_{10}$ measured at the three sites: Martinska, Zagreb north, and Zagreb south

Slika 7 - Srednje mjesečne koncentracije ukupnih PAU-a u lebdećim česticama zraka $\left(\mathrm{PM}_{10}\right)$ na tri mjerna mjesta: Martinska, Zagreb sjever i Zagreb jug

\section{Conclusions}

This paper presents the first measurements of $\mathrm{PAHs}$ in $\mathrm{PM}_{10}$ particle fraction in the middle coastal area of Croatia (Martinska near Šibenik). The average total PAH concentrations were $0.902 \mathrm{ng} \mathrm{m}^{-3}$. PAH mass concentrations in the coastal area were compared with $\mathrm{PAH}$ levels at two urban stations in central Croatia (Zagreb). At all three measuring sites, the highest mass concentration was recorded for BbF, BghiP and IP, while the contributions of Flu and Pyr to the $\mathrm{PM}_{10}$ were higher at the Martinska location. Relatively low PAH mass concentrations were measured in the coastal area, compared to the continental urban Croatia, as well as in comparison with literature data for the region. Statistically significant differences between sites were found for all $\mathrm{PAHs}$, indicating variabilities in dominant emission sources. Contributions of specific 5- and 6-ringed PAHs to the $\mathrm{PM}_{10}$ mass indicated traffic as a dominant PAHs source at all three location, especially at Zagreb south. High contributions of four-ringed PAHs (Flu and Pyr) as well as increased $\mathrm{BaP}$ concentrations at Martinska indicated that domestic heating as well as open-fire events, including agricultural waste incineration, which are frequent for the area, could probably affect the increase in PAH levels in the coastal area of Croatia. Since there are no available data on the PAH levels in ambient aerosols in the middle Adriatic coast thus far, the present study serves as a background for comparisons with future studies related to various specific sources of organic pollutants as well as air quality conditions in Adriatic coastal and/or Mediterranean regions.

\section{ACKNOWLEDGEMENTS}

This study has been fully financed by the Croatian Science Foundation under the project BiREADI (grant HRZZ-IP-2018-01-3105; PI: S. Frka).

\section{List of abbreviations and symbols Popis kratica i simbola}

PAHs
PM
$\mathrm{PM}_{10}$

- polycyclic aromatic hydrocarbons

- policiklički aromatski ugljikovodici

- particulate matter

- lebdeće čestice

- particles with an equivalent aerodynamic diameter less than $10 \mu \mathrm{m}$

- frakcija lebdećih čestica ekvivalentnog aerodinamičkog promjera manjeg od $10 \mu \mathrm{m}$

HPLC

- high-performance liquid chromatography

- tekućinski kromatograf visoke djelotvornosti

Flu

- fluoranthene

- fluoranten

Pyr

- pyrene

- piren

$\mathrm{BaA}$

- benzo(a)anthracene

- benzo(a)antracen

$\mathrm{BbF}$

- benzo(b)fluoranthene

- benzo(b)fluoranten

$\mathrm{BkF}$

- benzo(k)fluoranthene

- benzo(k)fluoranten

BjF

- benzo(j)fluoranthene

- benzo(j)fluoranten

BaP

- benzo(a)pyrene

- benzo(a)piren

DahA

- dibenzo(a,h)anthracene

- dibenzo(a,h)antracen

BghiP

- benzo(ghi)perylene

- benzo(ghi)perilen

IP

- indeno(1,2,3-cd)pyrene

- indeno(1,2,3-cd)piren

\section{References \\ Literatura}

1. WHO: Review of evidence on health aspect of air pollution REVIHAAP Project, World Health Organisation, WHO Regional Office for Europe, Copenhagen, 2013a.

2. S. Fuzzi, U. Baltensperger, K. Carslaw, S. Decesari, H. Denier van der Gon, M. C. Facchini, D. Fowler, I. Koren, B. Langforf, U. Lohmann, E. Nemitz, S. Pandis, I. Riipinen, Y. Rudich, M. Schaap, J. G. Slowik, D. V. Spracklen, E. Vignati, M. Wild, M. Williams, S. Gilardoni, Particulate matter, air quality and 
climate: lessons learned and future needs, Atmos. Chem. Phys. 15 (2015) 8217-8299,

doi: https://doi.org/10.5194/acp-15-8217-2015.

3. WHO: Air quality guidelines for particulate matter, ozone, nitrogen, dioxide and sulfur dioxide, World Health Organisation, 2005.

4. D. M. Agudelo-Castañeda, E. C. Teixeira, I. L. Schneider, S. A Rolim, N. Balzaretti, G. S. E. Silva, Comparison of emissivity, transmittance and reflectance infrared spectra of polycyclic aromatic hydrocarbons with those of atmospheric particulates $\left(\mathrm{PM}_{1}\right)$, Aerosol Air Qual. Res. 15 (2015) 1627-1639, doi: https://doi.org/10.4209/aaqr.2014.12.0329.

5. C. A. Belis, J. Cancelinha, M. Duane, V. Forcina, V. Pedroni, R. Passarella, G. Tanet, K. Douglas, A. Piazzalunga, E. Bolzacchini, G. Sangiorgi, M. G. Perrone, L. Ferrero, P. Fermo, B. R. Larsen, Sources for PM air pollution in the Po Plain, Italy: I. Critical comparison of methods for estimating biomass burning contributions to benzo(a)pyrene, Atmos. Environ. 45 (39) (2011) 7266-7275, doi: https://doi.org/10.1016/j.atmosenv.2011.08.061.

6. M. Masiol, A. Hofer, S. Squizzato, R. Piazza, G. Rampazzo, B. Pavoni, Carcinogenic and mutagenic risk associated to airborne particle-phase polycyclic aromatic hydrocarbons: a source apportionment, Atmos. Environ. 60 (2012) 375-382, doi: https://doi.org/10.1016/j.atmosenv.2012.06.073.

7. K. Ravindra, R. Sokhi, R. Van Grieken, Atmospheric polycyclic aromatic hydrocarbons: source attribution, emission factors and regulation, Atmos. Environ. 42 (2008) 2895-2921, doi: https://doi.org/10.1016/j.atmosenv.2007.12.010.

8. F. Chen, W. Hu, Q. Zhong, Emissions of particle-phase polycyclic aromatic hydrocarbons (PAHs) in the bFu Gui-shan Tunnel of Nanjing, China, Atmos. Res. 124 (2013) 53-60, doi: https://doi.org/10.1016/j.atmosres.2012.12.008.

9. J. Pooltawee, B. Pimpunchat, S. Junyapoon, Size distribution, characterization and risk assessment of particle-bound polycyclic aromatic hydrocarbons during haze periods in Phayao Province, northern Thailand, Air Qual. Atmos. Health 10 (9) (2017) 1097-1112,

doi: https://doi.org/10.1007/s11869-017-0497-5.

10. A. Alebić-Juretić, Airborne Polycyclic Aromatic Hydrocarbons in Suspended Particulates from the Urban Atmosphere of Rijeka, Croatia, Polycyclic aromatic compounds, 35 (2015) 91-101, doi: https://doi.org/10.1080/10406638.2014.922106.

11. I. Jakovljević, G. Pehnec, V. Vadjić, A. Šišović, S. Davila, I. Bešlić, Carcinogenic activity of polycyclic aromatic hydrocarbons bounded on particle fraction, Environ. Sci. Pollut. Res. 22 (2015) 20 15931-15940, doi: https://doi.org/10.1007/s11356-015-4777-z.

12. A. Šišović, G. Pehnec, I. Jakovljević, M. Šilović Hujić, V. Vadjić, I. Bešlić, Polycyclic aromatic hydrocarbons at different crossroads in Zagreb, Croatia, Bull. Environ. Contam. Toxicol. 88 (2012) 438-442,

doi: https://doi.org/10.1007/s00128-011-0516-4.
13. A. Šišović, M. Fugaš, Comparative evaluation of procedures for the determination of PAH in low-volume samples, Environ. Monit. Assess. 18 (1991) 235-241, doi: https://doi.org/10.1007/BF00398702.

14. P. Romagnoli, F. Vichi, C. Balducci, A. Imperiali, M. Perilli, L. Paciucci, F. Petracchini, A. Cecinato, Air quality study in the coastal city of Crotone (Southern Italy) hosting a small-size harbour, Environ. Sci. Pollut. Res. 24 (2017) 25260-25275, doi: https://doi.org/10.1007/s11356-017-0126-8.

15. I. Jakovljević, G. Pehnec, V. Vađić, M. Čačković, V. Tomašić, J. Doko Jelinić, Polycyclic aromatic hydrocarbons in PM10, PM2.5 and PM1 particle fraction in an urban area, Air Qual. Atmos. Health 11 (2018) 843-854, doi: https://doi.org/10.1007/s11869-018-0603-3.

16. G. Pehnec, I. Jakovljević, A. Šišović, I. Bešlić, V. Vađić, Influence of ozone and meteorological parameters on levels of polycyclic aromatic hydrocarbons in the air, Atmos. Environ. 131 (2016) 263-268, doi: https://doi.org/10.1016/j.atmosenv.2016.02.009.

17. M. S. Callén, J. M. López, A. M. Mastral, Seasonal variation of benzo(a)pyrene in the Spanish airborne $\mathrm{PM}_{10}$. Multivariate linear regression model applied to estimate BaP concentrations, J. Haz. Mat. 180 (2010) 648-655, doi: https://doi.org/10.1016/j.jhazmat.2010.04.085.

18. A. M. Caricchia, S. Chiavarini, M. Pezza, Polycyclic aromatic hydrocarbons in the urban atmospheric particulate matter in the city of Naples (Italy), Atmos. Environ. 33 (1999) 37313738 , doi: https://doi.org/10.1016/S1352-2310(99)00199-5.

19. M. lakovides, E. G. Stephanou, M. Apostolaki, M. Hadjicharalambous, J. S. Evans, P. Koutrakis, S. Achilleos, Study of the occurrence of airborne polycyclic aromatic hydrocarbons associated with respirable particles in two coastal cities at Eastern Mediterranean: Levels, source apportionment, and potential risk for human health, Atmos. Environ. 213 (2019) 170-184, doi: https://doi.org/10.1016/j.atmosenv.2019.05.059.

20. A. M. Mastral, M. S. Callén, J. M. López, R. Murillo, T. García, M. V. Navarro, Critical review on atmospheric PAH. Assessment of reported data in the Mediterranean basin, Fuel Process. Technol. 80 (2003) 183-193, doi: https://doi.org/10.1016/S0378-3820 (02)00249-7.

21. C. Alves, C. Pio, A. Duarte, Composition of extractable organic matter of air particles from rural and urban Portuguese areas, Atmos. Environ. 35 (2001) 5485-5496, doi: https://doi.org/10.1016/S1352-2310(01)00243-6.

22. M. Aceves, J. O. Grimalt, Seasonally dependent size distributions of aliphatic and polycyclic aromatic hydrocarbons in urban aerosols from densely populated areas, Environ. Sci. Techn. 27 (1993) 2896- 2908, doi: https://doi.org/10.1021/es00049a033.

23. URL: http://www.vatrogastvo-sibenik-knin.hr/ (20. 5. 2020.). 


\title{
SAŽETAK
}

\section{Usporedba masenih koncentracija PAU-a u lebdećim česticama zraka priobalnog područja srednjeg Jadrana i središnje Hrvatske}

\author{
Ivana Jakovljević, ${ }^{a}$ Zdravka Sever Štrukil, a Gordana Pehnec, ${ }^{a}$ Ivan Bešlić, Andrea Milinković, \\ Saranda Bakija Alempijevićb i Sanja Frka ${ }^{\text {b }}$
}

Policiklički aromatski ugljikovodici (PAU) zbog rasprostranjenosti, postojanosti, bioakumulacije i štetnih utjecaja na zdravlje ljudi te biljnog i životinjskog svijeta smatraju se prioritetnim onečišćujućim tvarima. Cilj istraživanja je po prvi put dobiti uvid u masene koncentracije specifičnih PAU-a u lebdećim česticama u zraku priobalnog područja srednjeg Jadrana te napraviti usporedbu $\mathrm{s}$ razinama PAU-a urbanog područja središnje Hrvatske. Koncentracije PAU-a u priobalnom području bile su relativno niske u odnosu na koncentracije u urbanoj središnjoj Hrvatskoj, gdje se i očekuju njihove povišene emisije uslijed znatno jačeg intenziteta prometa, industrije te izgaranja biomase uslijed loženja u kućanstvima. Veća zastupljenost PAU-a četirima aromatskim prstenovima (Flu i Pyr) u ukupnoj masi $\mathrm{PM}_{10}$ Čestica na mjernoj postaji Martinska upućuju na to da izgaranje drvne biomase uslijed grijanja kućanstava te uslijed požara otvorenog tipa mogu biti važan izvor PAU-a na obalnom dijelu srednjeg Jadrana.

\section{Ključne riječi}

Onečišćenje zraka, PAU, HPLC, BaP, lebdeće čestice, priobalna Hrvatska

\author{
a Institut za medicinska istraživanja i medicinu rada, \\ Ksaverska cesta 2, \\ 10000 Zagreb \\ b Zavod za istraživanje mora i okoliša, \\ Institut Ruđer Bošković, \\ Bijenička c. 54, 10000 Zagreb
}

Izlaganje sa znanstvenog skupa Prispjelo 21. travnja 2020. Prihvaćeno 15. lipnja 2020. 